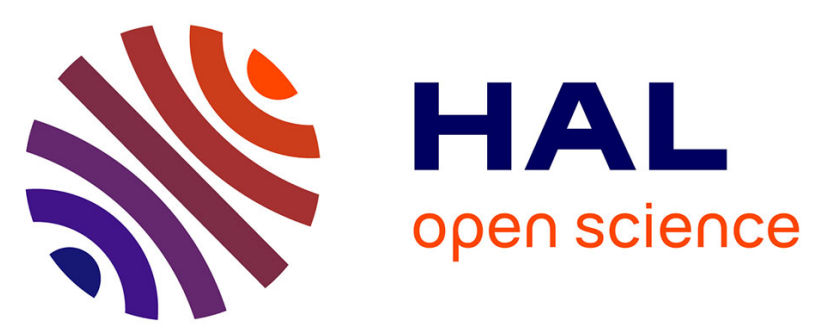

\title{
Extreme hydroclimate response gradients within the western Cape Floristic region of South Africa since the Last Glacial Maximum
}

Brian Chase, Arnoud Boom, Andrew Carr, Manuel Chevalier, Lynne J Quick, G. Anthony Verboom, Paula Reimer

\section{To cite this version:}

Brian Chase, Arnoud Boom, Andrew Carr, Manuel Chevalier, Lynne J Quick, et al.. Extreme hydroclimate response gradients within the western Cape Floristic region of South Africa since the Last Glacial Maximum. Quaternary Science Reviews, 2019, 219, pp.297-307. 10.1016/j.quascirev.2019.07.006 . hal-02264496

\section{HAL Id: hal-02264496 \\ https://hal.science/hal-02264496}

Submitted on 7 Oct 2020

HAL is a multi-disciplinary open access archive for the deposit and dissemination of scientific research documents, whether they are published or not. The documents may come from teaching and research institutions in France or abroad, or from public or private research centers.
L'archive ouverte pluridisciplinaire HAL, est destinée au dépôt et à la diffusion de documents scientifiques de niveau recherche, publiés ou non, émanant des établissements d'enseignement et de recherche français ou étrangers, des laboratoires publics ou privés. 


.
6 western Cape Floristic region of South Africa since the Last

Glacial Maximum

\section{The authors do not recommend the distribution of this version} of this article.

The article is freely available upon request. To receive a copy, please send a request to Brian Chase at: brian.chase@umontpellier.fr

Brian M. Chase ${ }^{*, a}$, Arnoud Boom $^{b}$, Andrew S. Carr ${ }^{b}$, Manuel Chevalier ${ }^{c}$, Lynne J. Quick ${ }^{d}$,

G. Anthony Verboom ${ }^{\mathrm{e}}$, Paula J. Reimer ${ }^{\mathrm{f}}$

anstitut des Sciences de l'Evolution-Montpellier (ISEM), University of Montpellier, Centre National de la Recherche Scientifique (CNRS), EPHE, IRD, Montpellier, France;

\footnotetext{
${ }^{b}$ School of Geography, Geology and the Environment, University of Leicester, Leicester, LE1 7RH, UK;
}

'Institute of Earth Surface Dynamics, Geopolis, University of Lausanne, Quartier UNIL-Mouline, Bâtiment Géopolis,

${ }^{d}$ African Centre for Coastal Palaeoscience, Nelson Mandela University, 6031 Port Elizabeth, South Africa: ${ }^{e}$ Department of Biological Sciences, University of Cape Town, 7700 Rondebosch, South Africa;

${ }^{f}$ School of Natural and Built Environment, Queen's University Belfast, Belfast, BT7 1NN, Northern Ireland, UK; 


\section{Abstract}

27 The Cape Floristic Region (CFR) is one of the world's major biodiversity hotspots, and much

28 work has gone into identifying the drivers of this diversity. Considered regionally in the context

29 of Quaternary climate change, climate stability is generally accepted as being one of the major

30 factors promoting the abundance of species now present in the CFR. However, little direct

31 evidence is available from the region, and responses to changes in global boundary conditions

32 have been difficult to assess. In this paper, we present new high-resolution stable isotope data

33 from Pakhuis Pass, in the species-rich western CFR, and contextualise our findings through

34 comparison with other records from the region. Combined, they indicate clear, coherent

35 changes in regional hydroclimate, which we relate to broader forcing mechanisms. However,

36 while these climate change events share similar timings (indicating shared macro-scale drivers),

37 the responses are distinct between sites, in some cases expressing opposing trends over very

38 short spatial gradients $(<50 \mathrm{~km})$. We describe the evolution of these trends, and propose that

39 while long-term $\left(10^{5} \mathrm{yr}\right)$ general climatic stability may have fostered high diversity in the region

40 through low extinction rates, the strong, abrupt changes in hydroclimate gradients observed in

41 our records may have driven a form of allopatric speciation pump, promoting the diversification

42 of plant lineages through the periodic isolation and recombination of plant populations. 


\section{Keywords}

44 Palaeoclimate, climate dynamics, South Africa, Cape Floristic Region, biodiversity, rock hyrax

45 middens, stable isotopes

\section{Highlights}

47 - New high resolution $\delta^{15} \mathrm{~N}$ data from rock hyrax middens from the western Cape Floristic 48 Region.

49 - Position of the southern westerlies apparent as a strong determinant of regional $50 \quad$ hydroclimates.

51 - High amplitude, rapid changes in hydroclimate are revealed in the region.

52 - Opposing responses to shared climate change events establish highly variable climate 53 gradients. 


\section{Introduction}

55 Southern African hydroclimate is primarily defined by the advection and precipitation of

56 moisture from tropical Atlantic and Indian Ocean sources during the austral summer (Figure 1).

57 In contrast, southwestern South Africa experiences a distinct, inverse rainfall regime. Seasonal

58 expansions of the circumpolar vortex and equatorward migration of the westerly storm track

59 bring increased precipitation during winter months, while displacements of the South Atlantic

60 Anticyclone during the summer intensify upwelling along the west coast, blocking the westward

61 propagation of easterly waves, generating strong summer drought in the region (Tyson, 1986;

62 Tyson and Preston-Whyte, 2000). During the Quaternary, southern Africa is thought to have

63 been sensitive to long-term changes in these tropical and temperate systems. Driven by

64 changes in global boundary conditions, tropical systems are invigorated during interglacial

65 periods and temperate systems exert increased influence during glacial periods (Chase et al.,

66 2015a; Chase et al., 2017; see Chase and Meadows, 2007; Cockroft et al., 1988; Quick et al.,

67 2011; van Zinderen Bakker, 1976).

This dynamic, which is thought to have become dominant in the Plio-Pleistocene (5.0 -

$692.6 \mathrm{Ma}$ ) when trade wind-controlled upwelling was established as a dominant factor in the

70 regional climate system (Diekmann et al., 2003), has created a Mediterranean climate zone in

71 the southwestern Cape of South Africa (Figure 2). This climatic evolution has been a key factor

72 in fostering the development of the vegetation of the Cape Floristic Region (CFR), which is

73 remarkable for its high level of endemism and its species richness (Cowling, 1992; Goldblatt,

74 1978). 
It has been recognised, however, that species diversity within the CFR, is not

76 homogeneous, with the winter-rain dominated western CFR having more than twice the species

77 per area of the eastern CFR, which currently experiences an aseasonal rainfall regime (Figure 2)

78 (Cowling et al., 1992; Cowling and Lombard, 2002; Cowling et al., 1997). During the Quaternary,

79 the western CFR has putatively experienced a continuous dominance of temperate systems,

80 whereas the eastern CFR rainfall regimes may have oscillated between temperate and tropical

81 rainfall dominance (see Chase and Meadows, 2007) with much more significant consequences

82 on the distribution and nature of environmental niches (Cowling et al., 1999; Cowling et al.,

83 1992). With a reliable climate regime, and relatively muted cycles of Quaternary climate change

84 compared to the extratropical regions in the Northern Hemisphere (see Chase and Meadows,

85 2007; Dynesius and Jansson, 2000), it is believed that the CFR's great floral diversity -

86 particularly in the west - is largely attributable to relative climatic stability and resulting low

87 extinction rates (Cowling et al., 1992; Cowling and Lombard, 2002; Cowling et al., 2015; Cowling

88 et al., 1997; Linder, 2005; Verboom et al., 2014). These hypotheses, and the conclusion that the

89 western CFR represented a more durable climatic niche than the eastern CFR is supported by

90 analyses of phylogenetic diversity, which indicate that the western CFR experienced higher

91 levels of in situ radiation, while the eastern CFR indicates significant mixing of lineages from

92 different biomes (Forest et al., 2007; Verboom et al., 2014).

93 At broad spatio-temporal scales, it thus seems apparent that the development of, and

94 the dynamics within, the southwestern Cape's Mediterranean climate region were fundamental

95 determinants for the evolution of the CFR. At finer spatial and temporal scales, these

96 considerations become more complex. In the western CFR, it has been observed that species 
97 richness is higher in the mountains than the lowlands, a situation related to topographic

98 variability and the resulting diversity of edaphic and climate spaces (Linder, 1991; Verboom et

99 al., 2015). Linder (1991) also found that species richness correlated most strongly with mean

100 annual precipitation, which might further suggest that climatic stability is a key determinant of

101 species diversity (as regions of currently high rainfall may be acting as interglacial refugia for

102 many CFR taxa (Chase and Meadows, 2007; Forest et al., 2007)). But how stable were climates

103 in these montane regions?

In this paper, we consider the climatic context of the high-diversity montane regions of

105 the western CFR in the light of new, high resolution palaeoclimatic data obtain from the region.

106 While neither spatially nor temporally comprehensive, it does enable the beginnings of a more

107 detailed analysis and understanding of the nature of climate change dynamics in the region.

108 While some studies have suggested long-term millennial-scale climate and vegetation stability

109 (Meadows et al., 2010; Meadows and Sugden, 1991), a growing body of data indicates

110 potentially more dynamic patterns of climate change, and further indicates that spatial climate

111 gradients may be much more complex than previously supposed (Chase et al., 2015a; Chase et

112 al., 2011). To address this, we present a new 19,300-year stable isotope composite record

113 derived from rock hyrax middens from Pakhuis Pass in the Cederberg Mountains. Considered

114 together with the records from other hyrax midden records from De Rif (Chase et al., 2015a;

115 Chase et al., 2011) and Katbakkies Pass (Chase et al., 2015b; Meadows et al., 2010), we are able

116 to assess the spatio-temporal dynamics of climate change along a modern climatic gradient in

117 the Cape Fold Belt Mountains of the western CFR - across the eastern slope of the Cederberg ,

118 and determine to what extent regional climates can be considered to be stable. 


\subsection{Regional setting}

120 Pakhuis Pass is located in the northern Cederberg Mountains, the dominant range of the north-

121 south axis of the Cape Fold Mountains to the east and northeast of Cape Town (Figures 2, 3).

122 Extending for $\sim 200 \mathrm{~km}$ parallel to the Atlantic Ocean (50-100 km to the west), this western limb

123 of the Cape Fold Belt is a significant divide between the relatively humid climates of the

124 southwestern Cape and the arid Karoo, which dominates much of South Africa's western

125 continental interior. The range also broadly marks the divide between southern Africa's two

126 major climate regimes: the winter rainfall zone (WRZ) to the west and the summer rainfall zone

127 (SRZ) to the northeast (cf. Chase and Meadows, 2007). The winter rainfall zone is defined by the

128 seasonal intensification and northward expansion of the westerlies and associated frontal

129 depressions that transport moisture to the region during the austral winter months. To the

130 east, and across most of South Africa, tropical easterly flow transports moisture from the Indian

131 Ocean during the austral summer. The Cederberg and adjacent ranges act as an orographic

132 divide between these climate zones, with the mountains creating a distinct rainshadow for

133 westerly derived rainfall (Figure 3; Tyson, 1986; Tyson and Preston-Whyte, 2000). The higher

134 elevations receive five times the precipitation of the lowlands to the east, but perhaps more

135 importantly, while the Cederberg Mountains receive more than $75 \%$ of their rainfall during the

136 winter, the lowlands to the east currently receive $50 \%$ or more of their precipitation during the

137 summer (Hijmans et al., 2005) (Figure 1).

138 Pakhuis Pass is located at $\sim 48$ m.a.s.I. on the eastern slopes of the Cederberg, in the 139 rainshadow of the Pakhuisberge massif ( 1000 m.a.s.I.) (Figure 3). Mean annual rainfall at the 140 site is $\sim 250-300 \mathrm{~mm} / \mathrm{yr}, \sim 80 \%$ of which falls in the austral winter between April and September 
141 (Hijmans et al., 2005). In comparison, the hyrax midden sites at De Rif (Chase et al., 2015a;

142 Chase et al., 2011; Quick et al., 2011) and Katbakkies Pass (Chase et al., 2015b; Meadows et al.,

143 2010) (Figure 2, 3) are both situated at $\sim 1150$ m.a.s.l., receive $\sim 400 \mathrm{~mm} / \mathrm{yr}$ and $\sim 300 \mathrm{~mm} / \mathrm{yr}$ of

144 mean annual rainfall respectively, and by virtue of their elevation and position relative to the

145 region's major topographic features they are more likely to receive precipitation during the

146 summer months through orographic amplification of local or larger synoptic-scale systems

147 (Tyson, 1986; Tyson and Preston-Whyte, 2000).

\section{Material and methods}

149 Middens for this study, PK08 and PK10-1 (Figure 4) were collected from the same 400 m long,

$15015 \mathrm{~m}$ high cliff band $\left(32.093^{\circ} \mathrm{S}, 19.065^{\circ} \mathrm{E}\right)$ as those described by Scott and Woodborne (2007a,

151 b) and were selected for their high hyraceum (crystallised urine) relative to faecal pellet

152 content. Apart from having greater structural integrity and less variable deposition rates,

153 hyraceum represents environmental conditions more clearly than samples containing faecal

154 pellets, which may potentially include a degree of dietary bias and often exhibit far more

155 discontinuous/irregular deposition (Chase et al., 2012). Sections of each midden were cut

156 perpendicular to the stratigraphy using an angle grinder and/or rotary impact hammer (Figure

157 4) and transported back to the laboratory for analysis. In addition to these newly collected 158 middens, we analysed one of the Pakhuis Pass middens (PK1173) considered in the papers of 159 Scott and Woodborne $(2007 a, b)$ 


\subsection{Chronology}

161 Radiocarbon age determinations for the PK08 and PK10-1 middens $(n=14)$ were processed at 162 the ${ }^{14} \mathrm{CHRONO}$ Centre, Queen's University Belfast using accelerator mass spectrometry (AMS)

163 (Table 1; Figure 5). Samples were pre-treated with $2 \% \mathrm{HCl}$ for one hour at room temperature to 164 remove carbonates and dried at $60^{\circ} \mathrm{C}$. They were then weighed into quartz tubes with an excess

165 of $\mathrm{CuO}$, sealed under vacuum and combusted to $\mathrm{CO}_{2}$. The $\mathrm{CO}_{2}$ was converted to graphite on an 166 iron catalyst using the zinc reduction method (Slota et al., 1987). The radiocarbon ages were 167 corrected for isotope fractionation using the AMS measured $\delta^{13} \mathrm{C}$. These ages and those 168 obtained from PK1173 (Scott and Woodborne, 2007a) were calibrated using the SHCal13 169 calibration data (Hogg et al., 2013). The Clam 2.2 software package (Blaauw, 2010) was used to 170 generate all age-depth models (Figure 5). Clam was chosen over Bayesian techniques such as

171 Bacon (Blaauw and Christen, 2011) because strong changes in accumulation rate may occur in 172 hyrax middens (such as PK08 and PK10-1), and Clam - using linear models - is better suited to 173 such sequences.

\section{$174 \quad 2.2$ Stable nitrogen isotopes}

175 Stable nitrogen isotope analysis of midden hyraceum samples were performed at the 176 Department of Archaeology, University of Cape Town following Chase et al. (2010; 2009), with a 177 contiguous/overlapping samples obtained two series of offset $1 \mathrm{~mm}$ holes. The standard 178 deviation derived from replicate analyses of homogeneous material was better than $0.2 \%$.

179 Results are expressed relative to atmospheric nitrogen. 


\section{Results}

\section{$181 \quad 3.1 \quad$ Chronology}

182 Radiocarbon analyses indicate that the Pakhuis Pass hyrax middens accumulated during the late 183 Pleistocene and Holocene, spanning the last 19,300 years cal (calibrated) BP. The age-depth 184 models for the two middens suggest continuous deposition, although accumulation rates do 185 vary considerably (Table 1; Figure 5). Accumulation rates for the PK08 midden average $\sim 28 \mu \mathrm{m}$ $186 \mathrm{yr}^{-1}$, with a period of more rapid accumulation centred on 6000 cal BP $\left(\sim 132 \mu \mathrm{m} \mathrm{yr}^{-1}\right)$. Each 1 $187 \mathrm{~mm}$ isotope sample from PK08 therefore integrates between 8 and 105 years of hyraceum 188 accumulation (averaging $42 \mathrm{~mm} \mathrm{yr}^{-1}$ ). Accumulation rates for the PK10-1 midden increase with 189 age/depth, from $\sim 2.6 \mu \mathrm{m} \mathrm{yr}^{-1}$ in the uppermost $30 \mathrm{~mm}$ to $\sim 106 \mu \mathrm{m} \mathrm{yr}{ }^{-1}$ in the bottom $13 \mathrm{~mm}$. 190 Therein, each $1 \mathrm{~mm}$ isotope sample from PK10-1 integrates between 380 years (upper section) 191 to 10 years (lower section) of hyraceum accumulation. Because of this significant change in 192 accumulation rate, we show data from the extremely low resolution of the Holocene portion of

193 PK10-1, but do not consider it our analyses, favouring? the much more highly resolved record 194 from PK08. Accumulation of the PK1173 midden (Scott and Woodborne, 2007a) was more 195 regular, averaging $50 \mu \mathrm{m} \mathrm{yr}^{-1}$, with each isotope sample integrating 20 years of accumulation.

\subsection{Stable nitrogen isotopes}

197 The $\delta^{15} \mathrm{~N}$ values from the PK08, PK10-1 and PK1173 middens vary from 3.6 to 8.6\%o (Figure 6).

198 Variations in midden $\delta^{15} \mathrm{~N}$ are interpreted to reflect changes in water availability (see more 199 extensive discussion in Chase et al., 2012). At the global scale, a relationship has been

200 recognised between aridity and foliar ${ }^{15} \mathrm{~N}$ (e.g. Craine et al., 2009; Hartman and Danin, 2010), 
201 and replication of this signal in plant and animal tissues and in faecal matter (e.g. Carr et al., 202 2016; Hartman, 2011; Murphy and Bowman, 2006; Newsome et al., 2011) has been 203 demonstrated. This is thought to be generally a function of a more open nitrogen cycle in arid 204 regions. Fractionating pathways in the soil (nitrification, denitrification, etc.) mean that 205 nitrogen lost through transformation and the release of gaseous products is depleted in ${ }^{15} \mathrm{~N}$, 206 and the remaining nitrogen is enriched. While in more humid regions $\mathrm{N}$ is cycled between live 207 and dead organic pools, in drier regions more $\mathrm{N}$ flows to mineral pools where it is subject to 208 gaseous loss (Amundson et al., 2003), and the $\delta^{15} \mathrm{~N}$ value of soils is thus higher with increasing 209 aridity (Austin and Vitousek, 1998; Handley et al., 1999; Murphy and Bowman, 2009). The 210 environmental processes relating to this recycling or loss of ${ }^{15} \mathrm{~N}$ are not tied exclusively to 211 rainfall amount, but in climatic terms are more accurately considered to relate to water 212 availability (Murphy and Bowman, 2006). Studies of ${ }^{15} \mathrm{~N}$ in hyrax middens from a wide range of 213 environments indicate consistently strong correlations between midden ${ }^{15} \mathrm{~N}$, local

214 vegetation/soil $15 \mathrm{~N}$, as well as independent climate proxy records, supporting the conclusion 215 that environmental moisture availability is a major driver of midden ${ }^{15} \mathrm{~N}$ records (Carr et al., 216 2016; Chase et al., 2015a; Chase et al., 2013; Chase et al., 2017; Chase et al., 2015b; Chase et 217 al., 2010; Chase et al., 2009; Chase et al., 2011).

218 This general relationship may also be influenced to some extent by other (e.g. 219 microclimatic) factors, as is reflected in the variability observed in the relationship between 220 modern foliar ${ }^{15} \mathrm{~N}$ and aridity estimates (e.g. Hartman and Danin, 2010; Murphy and Bowman, 221 2006; Peri et al., 2012). This influence can be observed in the offset between the PK08 and 222 PK1173 records and the record from PK10-1 (Figure 6). This is not uncommon when comparing 
223 records from different middens, even when in relatively close proximity $(<20 \mathrm{~m})$ (Chase et al.,

224 2013). These differences are believed to be driven by micro-topographic variations influencing

225 water-availability in the primary feeding zones associated with each shelter (cf. Chase et al., 226 2013; Chase et al., 2017). In the case of the Pakhuis Pass middens, PK10-1 was retrieved from a

227 narrow upper tier of the cliff complex, with the primary foraging range was likely to have been

228 dominated by plants able to establish in the exposed landscape and thin soils found on the rock

229 shelves above the cliff. PK08 and PK1173, in contrast, are located near the cliff base, and

230 surrounded by deeper soils and higher groundwater recharge potential, which supports a more

231 mesic, denser vegetation. The result is that while trends in $\delta^{15} \mathrm{~N}$ variability are similar between

232 the PK08, PK1173 and PK10-1 middens, the PK10-1 values are approximately 0.95\% higher

233 (established by comparison of average values for the overlapping sections of midden

234 sequences). For combination and consideration of the records, we have applied a $0.95 \%$

235 correction factor to the PK10-1 data.

To create a single composite record, we selected the PK08 record over the much lower

237 resolution PK10-1 record for the mid- to late Holocene, as the latter is little informative in this

238 context, with greater temporal averaging attenuating the variability evident in the higher

239 resolution PK08 record. For the late Pleistocene, PK10-1 and PK1173 are of similar resolution

240 and indicate similar trends. To incorporate information from both middens, we combined and

241 smoothed the age-ranked data ensemble using Gaussian kernel-based interpolation (Rehfeld et

242 al., 2011). This technique has been shown to be the most appropriate to interpolate irregularly

243 sampled time series. We followed the recommendation of Rehfeld et al. (2011) and used the

244 average temporal resolution of the data from these sections (31.97 years) to define the width 
245 of our Gaussian kernel. To maintain the true temporal resolution of our composite record, the

246 values were interpolated at the sample ages.

247 As a whole, the Pakhuis Pass $\delta^{15} \mathrm{~N}$ data indicate a general aridification at the site (change

248 towards higher $\delta^{15} \mathrm{~N}$ values) from the late Pleistocene to the Holocene (Figure 6). The most

249 humid periods recorded occur during the last glacial period, between 19,300 and 15,300 cal BP,

250 and from $6100-5500$ cal BP, following the early to mid-Holocene transition. Maximum aridity is

251 reached during the early Holocene. The length and resolution of the records do not allow for

252 definitive comparisons, but variability during the Pleistocene portion of the record - even

253 considering its lower resolution - appears relatively muted compared to the strong, abrupt

254 changes apparent in the Holocene.

255 Using change point analysis (Killick et al., 2012; Trauth et al., 2018), major transitions in

256 the mean climate state (not accounting for changes in variability) in the record (where the root-

257 mean-square level of the signal changes most significantly) were identified. Most notably, the

258 period following the termination of early Holocene aridity at 6800 cal BP is marked by a series

259 of abrupt changes reflecting a rapid increase in water availability between 6800 and 6140 cal

260 BP. This period of relatively humid conditions ends equally abruptly, with distinctly drier

261 conditions persisting from 5520 - 4480 cal BP. A subsequent sharp increase in water availability

262 is followed by a gradual aridification between 4480 and 2830 cal BP, and apparently more

263 stable conditions during the late Holocene. It is worth noting that the amplitude of change

264 registered across these transitions (as much as $4.5 \%$ ) is similar to the amplitude of change

265 between the Last Glacial Maximum and Holocene (5\%०). Using the data derived from modern 
266 hyrax faecal pellets presented by Carr et al. (2016), this may speculatively be translated to a

$267 \sim 70 \%$ increase in water availability (Aridity Index from 0.25 to 0.42 ) for the period between

$268 \sim 6800$ and 6100 cal BP (Figure 6). Unfortunately, the midden records obtained do not provide

269 detailed information regarding modern/sub-modern conditions, and a full contextualisation of

270 these results in comparison with modern climates and recent change is not yet possible.

\section{Discussion}

\section{$272 \quad$ G.1 Glacial-interglacial scale variability}

273 Considering the combined influences of lower Pleistocene temperatures (Chevalier and Chase, 274 2016; Lim et al., 2016; Stute and Talma, 1998; Talma and Vogel, 1992), and the position of

275 Pakhuis Pass in the winter rainfall zone, which is considered to have received increased 276 precipitation during glacial periods (Chase et al., 2017; Chase and Meadows, 2007; Cockcroft et 277 al., 1987; van Zinderen Bakker, 1976), it is not surprising that the late Pleistocene is 278 characterised by more humid conditions (Figure 7). What is most remarkable about the Pakhuis 279 Pass $\delta^{15} \mathrm{~N}$ record is that it indicates dramatically different patterns of change than those 280 recorded at the De Rif hyrax midden site, located only $42 \mathrm{~km}$ to the south (Figure 2,3; Chase et 281 al. 2011, 2015). This implies past climate change dynamics characterised by marked levels of 282 spatio-temporal heterogeneity. Previously, inter-regional differences have been indicated by $283 \delta \delta^{15} \mathrm{~N}$ records from Seweweekspoort (Figure 2; $230 \mathrm{~km}$ east-southeast of De Rif). In isolation, the 284 differences between the De Rif and Seweweekspoort might otherwise have been explained by 285 the distinct natures of eastern and western CFR climate histories (Chase and Meadows, 2007; 286 Cowling et al., 1992). The new data from Pakhuis Pass imply a more complex dynamic. 
Interpretations of the Seweweekspoort and De Rif records, which extend into the Last

288 Glacial Maximum (LGM; 19-26.5 ka (Clark et al., 2009)) have highlighted the influence of

289 different elements of the regional climate system as they were impacted by changing global

290 boundary conditions. At glacial-interglacial timescales, the $\delta^{15} \mathrm{~N}$ record from Seweweekspoort

291 (Chase et al., 2017) has been identified as primarily reflecting changes in the climate system

292 related to global temperature and Antarctic sea-ice, which has been hypothesised as being a

293 significant control on the position of the southern westerlies storm track (Chase and Meadows,

294 2007; Cockcroft et al., 1987; van Zinderen Bakker, 1976). In contrast, at De Rif, despite being

295 closer to the core of the WRZ, where temperate systems define the modern regional rainfall

296 regime, the primary control on hydrologic balance at millennial and multi-millennial timescales

297 appears to be variations in the length and intensity of the summer drought season, potentially

298 modulated by variations in the intensity of the South Atlantic Anticyclone, which blocks the

299 incursion of tropical air masses and limits convection (Chase et al., 2015a). In the higher

300 elevations of the Cederberg mountains, while winter rainfall is consistent and abundant,

301 changes in summer rainfall may have had a more significant influence on driving drought-stress

302 at the site. Including the new Pakhuis Pass $\delta^{15} \mathrm{~N}$ record in this regional consideration, it seems

303 likely (based on similarities in first-order trends with SWP, as well as EPICA Dronning Maud Land

304 ice core sea-salt sodium flux record, considered as a general proxy for sea-ice extent (Fischer et

305 al., 2007)) that at glacial-interglacial timescales conditions at Pakhuis Pass is predominantly

306 impacted by changes in temperate system influence, with summer rainfall playing a relatively

307 limited role in defining water availability. 


\subsection{The Holocene}

309 Focussing on the Holocene, more, and more precise data can be brought to bear on the

310 question of CFR climate dynamics. While data coverage remains far from comprehensive, high

311 resolution stable isotope data from rock hyrax middens have provided important clues as to

312 some of the drivers and spatial dynamics that have defined climate change in the region during

313 the Holocene (Figure 8). Building from the basis of the conceptual models developed by van

314 Zinderen Bakker (1976) and Cockcroft et al. (1987), which indicate that periods of global cooling

315 (warming) will generally result in wetter (drier) conditions in the WRZ (SRZ), and that a coeval

316 inverse relationship in terms of precipitation amount exists between the two regions, more

317 nuanced scenarios regarding observed variability are being proposed.

318 To constrain the relationship between CFR climate dynamics and the underlying drivers

319 of the observed variability, we have considered the diatom-based Atlantic sector sea-ice extent

320 and Southern Ocean summer sea-surface temperature (SSST) reconstructions of Nielsen et al.

321 (2004) from marine core TN057-17. Similarities with these records can be observed at sites

322 across the CFR, but it appears that the relationship between humidity and mid-latitude SSSTs

323 changes from positive to negative moving from the eastern to western CFR. At the coastal

324 eastern CFR site of Eilandvlei (Quick et al., 2018), for example, higher percentages of

325 afrotemperate forest pollen (considered to indicate increased humidity and reduced drought

326 stress) correlate well with higher SSSTs at TN057-17 (Figure 8). In contrast, higher humidity at

327 Pakhuis and Katbakkies passes are more clearly linked to lower SSSTs. Climatically, this most

328 likely indicates that increased westerly influence results in more humid conditions in the lee of 
329 the Cederberg mountains, perhaps related to a greater frequency of more powerful frontal 330 systems.

Considering the relationship between the Pakhuis and Katbakkies pass sites, the impact

332 of changes in westerly influence is variable even between these two sites, despite their

333 proximity and their shared position in the lee of the Cederberg. Katbakkies Pass $\delta^{15} \mathrm{~N}$ record

334 exhibits changes in both the timing and amplitude that are similar to changes in TN057-17

335 SSSTs, perhaps indicating that variations in humidity are more tightly coupled to temperate

336 frontal systems than at Pakhuis Pass, where the timing and direction of the anomalies is shared,

337 but the local response is less consistent (Figure 8). As has been indicated (Chase et al., 2017),

338 increased frontal activity during the Holocene is not necessarily inconsistent with the increases

339 in summer rain that have been previous suggested to drive moisture availability at Katbakkies

340 Pass (Chase et al., 2015b), but it is clear that further work is required to adequately understand

341 how temperate and tropical systems interact to create precipitation events in the region on the

342 timescales considered here.

343 Underscoring the regional heterogeneity and the variable influence of the region's

344 moisture bearing systems, the Holocene record from De Rif once again is markedly different

345 from the Pakhuis and Katbakkies pass sites (Figure 8). Whereas the Pakhuis and Katbakkies Pass

346 records exhibit a generally negative relationship between humidity and TN057-17 SSSTs, at De

347 Rif the relationship is generally positive, with more humid conditions occurring during periods

348 of relatively elevated SSSTs. In the early Holocene, while sea ice presence is low in the Atlantic

349 sector of the Southern Ocean, conditions at De Rif are at their most humid for the last 19,400 
350 years. With cooling SSSTs and increased sea ice presence after 7000 cal BP, conditions become

351 significantly drier. This extreme change during the early to mid-Holocene transition exemplifies

352 the apparently sharply contrasting trends across the region, with the records from both Pakhuis

353 and Katbakkies pass showing a strong increase in humidity evident from $7000-6000$ cal BP.

354 While more muted, this coeval inverse relationship between the Pakhuis and Katbakkies Pass

355 passes? sites and the De Rif persists throughout the Holocene, indicating that conditions at all

356 of the sites are controlled by a shared dynamic, but that opposing factors determine conditions

357 in the mountains (De Rif) and the rainshadow (Pakhuis and Katbakkies passes).

Of particular significance is how the opposing responses affect climatic gradients across

359 the region. During the early Holocene, based on the $\delta^{15} \mathrm{~N}$ data, a very strong hydroclimatic

360 gradient existed along the eastern slope of the Cederberg Mountains (Figure 9). Following the

361 early to mid-Holocene transition, this gradient became much weaker, with more similar

362 hydroclimatic conditions existing between the western CFR sites considered here. While only

363 the records from De Rif and Pakhuis Pass extend to the Last Glacial Maximum, indications are

364 that these gradients were weakened even further during the late Pleistocene, with similar $\delta^{15} \mathrm{~N}$

365 values at both sites suggesting nearly equivalent hydroclimatic conditions.

We hypothesise that these changes in environmental gradients may have had a

367 significant influence on the diversity and distinction of environmental niches in the region, and

368 that changes in these gradients may have acted as locks for gene flow, serving to alternatively

369 isolate or enable the migration and mixing of plant species across the region. Considering the

370 observation that species richness in the western CFR is higher in montane regions, the data 
371 presented here provide palaeoclimatic evidence that highly variable spatial environmental

372 gradients may have acted as a kind of allopatric speciation pump (e.g. Goldblatt and Manning,

373 2002; Haffer, 1969; Linder, 1985; Linder, 2003; Verboom et al., 2015), with the repeated

374 isolation and mixing of promoting the exceptionally high species diversity of the CFR.

375 Further work will be required to establish where and to what extent variability on the

376 scale discussed in this paper has been biologically significant. Has the degree or rate of change

377 exceeded the tolerance of specific plant species or their ability to migrate? Can the spatial

378 configuration of climate response anomalies be reliably linked to spatial patterns of species

379 richness? Or, are the changes observed in the records discussed largely insignificant, and play

380 no consequential role in determining species richness. Studies of fossil pollen records from the

381 region provide a mixed response, with some indicating only minor changes in vegetation

382 composition during the late Pleistocene and Holocene (Meadows et al., 2010; Meadows and

383 Sugden, 1991), while other indicate substantial changes in vegetation have occurred (Scott and

384 Woodborne, 2007a; Valsecchi et al., 2013). To adequately evaluate and compare these findings,

385 more sites from transects across the region will need to be studied using a consistent

386 methodology that employs a range of proxies capable of differentiating climate and vegetation

387 change, and assessing spatial patterns of genetic diversity.

\section{Conclusions}

389 - We present a new, high resolution $\delta^{15} \mathrm{~N}$ record from Pakhuis Pass in the Cederberg $390 \quad$ Mountains of the western Cape Floristic Region. 
- Like recently published records from the region (Chase et al., 2015a; Chase et al., 2015b), the data from Pakhuis Pass indicate substantial, rapid changes in hydroclimatic conditions, contrasting with earlier suggestions that the Cederberg experienced relatively little environmental change during since the LGM (Meadows et al., 2010; Meadows and Sugden, 1991).

- The record from Pakhuis Pass indicates similarities with patterns of change observed in comparable records from Katbakkies Pass ((Chase et al., 2015b), also in the rainshadow of the Cederberg) but contrasts sharply with conditions at De Rif (Chase et al., 2015a), where a coeval inverse pattern of variability is observed. Commonalities in the timing of change suggest a shared driver of regional climate dynamics, but distinct local responses, perhaps as a function of orographic influences.

- While hydroclimatic conditions at Pakhuis Pass and De Rif may have been similar gradient between the sites.

- We hypothesise that changes in the slope of this gradient likely reflect similar patterns across the region, and that these changes may have driven an allopatric speciation pump, contributing to the elevated species diversity observed in the montane regions of the western CFR. 
- The spatial heterogeneity of hydroclimatic conditions suggested by the data included in this study indicates the need for more sites and comparable data from across the CFR in order to resolve the complexity of response to long-term climate change.

\section{Acknowledgements}

416 The research leading to these results has received funding from the European Research Council

417 under the European Union's Seventh Framework Programme (FP7/2007-2013), ERC Starting

418 Grant "HYRAX", grant agreement no. 258657. We are very grateful to Louis Scott for providing a

419 portion of the PK1173 midden for analysis.

\section{References}

421 Amundson, R., Austin, A.T., Schuur, E.A.G., Yoo, K., Matzek, V., Kendall, C., Uebersax, A., 422 Brenner, D., Baisden, W.T., 2003. Global patterns of the isotopic composition of soil and plant 423 nitrogen. Global Biogeochemical Cycles 17.

424 Austin, A.T., Vitousek, P.M., 1998. Nutrient dynamics on a precipitation gradient in Hawai'i. 425 Oecologia 113, 519-529.

426 Blaauw, M., 2010. Methods and code for 'classical' age-modelling of radiocarbon sequences. 427 Quaternary Geochronology 5, 512-518.

428 Blaauw, M., Christen, J.A., 2011. Flexible paleoclimate age-depth models using an autoregressive gamma process. Bayesian Analysis 6, 457-474. hyrax faecal pellets, hyraceum and associated vegetation in southern Africa: Implications for dietary ecology and palaeoenvironmental reconstructions. Journal of Arid Environments 134, 3348.

Chase, B.M., Boom, A., Carr, A.S., Carré, M., Chevalier, M., Meadows, M.E., Pedro, J.B., Stager, J.C., Reimer, P.J., 2015a. Evolving southwest African response to abrupt deglacial North Atlantic climate change events. Quaternary Science Reviews 121, 132-136.

Chase, B.M., Boom, A., Carr, A.S., Meadows, M.E., Reimer, P.J., 2013. Holocene climate change in southernmost South Africa: rock hyrax middens record shifts in the southern westerlies. Quaternary Science Reviews 82, 199-205.

440 Chase, B.M., Chevalier, M., Boom, A., Carr, A.S., 2017. The dynamic relationship between 441 temperate and tropical circulation systems across South Africa since the last glacial maximum. 442 Quaternary Science Reviews 174, 54-62. 
Chase, B.M., Lim, S., Chevalier, M., Boom, A., Carr, A.S., Meadows, M.E., Reimer, P.J., 2015 b. Influence of tropical easterlies in southern Africa's winter rainfall zone during the Holocene. Quaternary Science Reviews 107, 138-148. rainfall zone. Earth-Science Reviews 84, 103-138.

Chase, B.M., Meadows, M.E., Carr, A.S., Reimer, P.J., 2010. Evidence for progressive Holocene aridification in southern Africa recorded in Namibian hyrax middens: implications for African Monsoon dynamics and the "African Humid Period". Quaternary Research 74, 36-45.

Chase, B.M., Meadows, M.E., Scott, L., Thomas, D.S.G., Marais, E., Sealy, J., Reimer, P.J., 2009. A record of rapid Holocene climate change preserved in hyrax middens from southwestern Africa. Geology 37, 703-706.

Chase, B.M., Quick, L.J., Meadows, M.E., Scott, L., Thomas, D.S.G., Reimer, P.J., 2011. Late glacial interhemispheric climate dynamics revealed in South African hyrax middens. Geology 39, 19-22.

Chase, B.M., Scott, L., Meadows, M.E., Gil-Romera, G., Boom, A., Carr, A.S., Reimer, P.J., Truc, L., Valsecchi, V., Quick, L.J., 2012. Rock hyrax middens: a palaeoenvironmental archive for southern African drylands. Quaternary Science Reviews 56, 107-125.

Chevalier, M., 2019. Enabling possibilities to quantify past climate from fossil assemblages at a global scale. Global and Planetary Change 175, 27-35.

Chevalier, M., Chase, B.M., 2016. Determining the drivers of long-term aridity variability: a southern African case study. Journal of Quaternary Science 31, 143-151.

Clark, P.U., Dyke, A.S., Shakun, J.D., Carlson, A.E., Clark, J., Wohlfarth, B., Mitrovica, J.X., Hostetler, S.W., McCabe, A.M., 2009. The Last Glacial Maximum. Science 325, 710-714.

Cockcroft, M.J., Wilkinson, M.J., Tyson, P.D., 1987. The application of a present-day climatic model to the late Quaternary in southern Africa. Climatic Change 10, 161-181.

Cockroft, M.J., Wilkinson, M.J., Tyson, P.D., 1988. A palaeoclimatic model for the late Quaternary in southern Africa. Palaeoecology of Africa 19, 279-282.

Cowling, R.M., 1992. The Ecology of Fynbos: Nutrients, Fire, and Diversity. Oxford University Press, Cape Town.

Cowling, R.M., Cartwright, C.R., Parkington, J.E., Allsopp, J.C., 1999. Fossil wood charcoal assemblages from Elands Bay Cave, South Africa: implications for Late Quaternary vegetation and climates in the winter-rainfall fynbos biome. Journal of Biogeography 26, 367-378.

Cowling, R.M., Holmes, P.M., Rebelo, A.G., 1992. Plant diversity and endemism, in: Cowling, R.M. (Ed.), Ecology of fynbos. Nutrients, Fire and Diversity. Oxford University Press, Cape Town, pp. 62-112.

Cowling, R.M., Lombard, A.T., 2002. Heterogeneity, speciation/extinction history and climate: explaining regional plant diversity patterns in the Cape Floristic Region. Diversity and Distributions 8, 163-179.

Cowling, R.M., Potts, A.J., Bradshaw, P.L., Colville, J., Arianoutsou, M., Ferrier, S., Forest, F., Fyllas, N.M., Hopper, S.D., Ojeda, F., Procheş, Ş., Smith, R.J., Rundel, P.W., Vassilakis, E., Zutta, B.R., 2015. Variation in plant diversity in mediterranean-climate ecosystems: the role of climatic and topographical stability. Journal of Biogeography 42, 552-564.

Cowling, R.M., Richardson, D.M., Schulze, R.J., Hoffman, M.T., Midgley, J.J., Hilton-Taylor, C., 1997. Species diversity at the regional scale, in: Cowling, R.M., Richardson, D.M., Pierce, S.M. (Eds.), Vegetation of Southern Africa. Cambridge University Press, Cambridge, pp. 447473. 
Craine, J.M., Elmore, A.J., Aidar, M.P.M., Bustamante, M., Dawson, T.E., Hobbie, E.A., Kahmen, A., Mack, M.C., McLauchlan, K.K., Michelsen, A., Nardoto, G.B., Pardo, L.H., Peñuelas, J., Reich, P.B., Schuur, E.A.G., Stock, W.D., Templer, P.H., Virginia, R.A., Welker, J.M., Wright, I.J., 2009. Global patterns of foliar nitrogen isotopes and their relationships with climate, mycorrhizal fungi, foliar nutrient concentrations, and nitrogen availability. New Phytologist 183, 980-992.

Diekmann, B., Falker, M., Kuhn, G., 2003. Environmental history of the south-eastern South Atlantic since the Middle Miocene: evidence from the sedimentological records of ODP Sites 1088 and 1092. Sedimentology 50, 511-529.

Dynesius, M., Jansson, R., 2000. Evolutionary consequences of changes in species' geographical distributions driven by Milankovitch climate oscillations. Proceedings of the National Academy of Sciences 97, 9115-9120.

Fischer, H., Fundel, F., Ruth, U., Twarloh, B., Wegner, A., Udisti, R., Becagli, S., Castellano, E., Morganti, A., Severi, M., Wolff, E., Littot, G., Röthlisberger, R., Mulvaney, R., Hutterli, M.A., Kaufmann, P., Federer, U., Lambert, F., Bigler, M., Hansson, M., Jonsell, U., de Angelis, M., Boutron, C., Siggaard-Andersen, M.-L., Steffensen, J.P., Barbante, C., Gaspari, V., Gabrielli, P., Wagenbach, D., 2007. Reconstruction of millennial changes in dust emission, transport and regional sea ice coverage using the deep EPICA ice cores from the Atlantic and Indian Ocean sector of Antarctica. Earth and Planetary Science Letters 260, 340-354.

Forest, F., Grenyer, R., Rouget, M., Davies, T.J., Cowling, R.M., Faith, D.P., Balmford, A., Manning, J.C., Procheș, Ş., van der Bank, M., Reeves, G., Hedderson, T.A.J., Savolainen, V., 2007. Preserving the evolutionary potential of floras in biodiversity hotspots. Nature 445, 757 .

GBIF.org, 2018a. Anthocerotopsida occurrence data downloaded on September 13th. GBIF.org. GBIF.org, 2018b. Cycadopsidae occurrence data downloaded on March 30th. GBIF.org. GBIF.org, 2018c. Gingkoopsidae occurrence data downloaded on March 30th. GBIF.org. GBIF.org, 2018d. Gnetopsidae occurrence data downloaded on March 30th. GBIF.org. GBIF.org, 2018e. Liliopsida occurrence data downloaded on September 13th. GBIF.org. GBIF.org, 2018f. Lycopodiopsida occurrence data downloaded on September 13th. GBIF.org. GBIF.org, 2018g. Magnoliopsida occurrence data downloaded on March 30th. GBIF.org. GBIF.org, 2018h. Pinopsidae occurrence data downloaded on March 30th. GBIF.org. GBIF.org, 2018i. Polypodiopsida occurrence data downloaded on September 13th. GBIF.org. Goldblatt, P., 1978. An analysis of the flora of southern Africa: its characteristics, relationships, and origins. Annals of the Missouri Botanical Garden 65, 369-436.

Goldblatt, P., Manning, J.C., 2002. Plant diversity of the Cape Region of southern Africa. Annals of the Missouri Botanical Garden 89, 281-302.

Haffer, J., 1969. Speciation in Amazonian Forest Birds. Science 165, 131-137. Handley, L.L., Austin, A.T., Stewart, G.R., Robinson, D., Scrimgeour, C.M., Raven, J.A., Heaton, T.H.E., Schmidt, S., 1999. The ${ }^{15} \mathrm{~N}$ natural abundance $\left(\delta^{15} \mathrm{~N}\right)$ of ecosystem samples reflects measures of water availability. Functional Plant Biology 26, 185-199.

Hartman, G., 2011. Are elevated $\delta^{15} \mathrm{~N}$ values in herbivores in hot and arid environments caused by diet or animal physiology? Functional Ecology 25, 122-131.

Hartman, G., Danin, A., 2010. Isotopic values of plants in relation to water availability in the Eastern Mediterranean region. Oecologia 162, 837-852.

Hijmans, R., Cameron, S.E., Parra, J.L., Jones, P.G., Jarvis, A., 2005. Very high resolution interpolated climate surfaces for global land areas. International Journal of Climatology 25, 1965-1978. 
Hogg, A.G., Hua, Q., Blackwell, P.G., Niu, M., Buck, C.E., Guilderson, T.P., Heaton, T.J., Palmer, J.G., Reimer, P.J., Reimer, R.W., Turney, C.S.M., Zimmerman, S.R.H., 2013. SHCal13 Southern Hemisphere Calibration, 0-50,000 Years cal BP. Radiocarbon 55, 1889-1903. Killick, R., Fearnhead, P., Eckley, I.A., 2012. Optimal Detection of Changepoints With a Linear Computational Cost. Journal of the American Statistical Association 107, 1590-1598. change in the southern Namib Desert, Pella, South Africa. Palaeogeography, Palaeoclimatology, Palaeoecology 451, 197-209.

Linder, H.P., 1985. Gene flow, speciation, and species diversity patterns in a species-rich area: the Cape Flora. Species and speciation 4, 53-57.

Linder, H.P., 1991. Environmental correlates of patterns of species richness in the south-western Cape Province of South Africa. Journal of Biogeography 18, 509-518. Linder, H.P., 2003. The radiation of the Cape flora, southern Africa. Biological Reviews of the Cambridge Philosophical Society 78, 597-638.

Linder, H.P., 2005. Evolution of diversity: the Cape flora. Trends in Plant Science 10, 536-541.

Meadows, M.E., Chase, B.M., Seliane, M., 2010. Holocene palaeoenvironments of the Cederberg and Swartruggens mountains, Western Cape, South Africa: Pollen and stable isotope evidence from hyrax dung middens. Journal of Arid Environments 74, 786-793.

Meadows, M.E., Sugden, J.M., 1991. A vegetation history of the last 14,000 years on the Cederberg, southwestern Cape Province. South African Journal of Science 87, 34-43.

Mucina, L., Rutherford, M.C., 2006. The vegetation of South Africa, Lesotho and Swaziland, Strelitzia. South African National Biodiversity Institute, Pretoria.

Murphy, B.P., Bowman, D.M.J.S., 2006. Kangaroo metabolism does not cause the relationship between bone collagen $\delta^{15} \mathrm{~N}$ and water availability. Functional Ecology 20, 1062-1069.

Murphy, B.P., Bowman, D.M.J.S., 2009. The carbon and nitrogen isotope composition of Australian grasses in relation to climate. Functional Ecology 23, 1040-1049.

Newsome, S.D., Miller, G.H., Magee, J.W., Fogel, M.L., 2011. Quaternary record of aridity and mean annual precipitation based on $\delta^{15} \mathrm{~N}$ in ratite and dromornithid eggshells from Lake Eyre, Australia. Oecologia 167, 1151-1162.

Nielsen, S.H.H., Koç, N., Crosta, X., 2004. Holocene climate in the Atlantic sector of the Southern Ocean: Controlled by insolation or oceanic circulation? Geology 32, 317-320.

Peri, P.L., Ladd, B., Pepper, D.A., Bonser, S.P., Laffan, S.W., Amelung, W., 2012. Carbon $\left(\delta^{13} \mathrm{C}\right)$ and nitrogen $\left(\delta^{15} \mathrm{~N}\right)$ stable isotope composition in plant and soil in Southern Patagonia's native forests. Global Change Biology 18, 311-321.

Quick, L.J., Chase, B.M., Meadows, M.E., Scott, L., Reimer, P.J., 2011. A 19.5 kyr vegetation history from the central Cederberg Mountains, South Africa: Palynological evidence from rock hyrax middens. Palaeogeography, Palaeoclimatology, Palaeoecology 309, 253-270.

Quick, L.J., Chase, B.M., Wündsch, M., Kirsten, K.L., Chevalier, M., Mäusbacher, R., Meadows, M.E., Haberzettl, T., 2018. A high-resolution record of Holocene climate and vegetation dynamics from the southern Cape coast of South Africa: pollen and microcharcoal evidence from Eilandvlei. Journal of Quaternary Science 33, 487-500.

Rehfeld, K., Marwan, N., Heitzig, J., Kurths, J., 2011. Comparison of correlation analysis techniques for irregularly sampled time series. Nonlin. Processes Geophys. 18, 389-404.

579 Roberts, D.L., Neumann, F.H., Cawthra, H.C., Carr, A.S., Scott, L., Durugbo, E.U., Humphries, M.S., Cowling, R.M., Bamford, M.K., Musekiwa, C., MacHutchon, M., 2017. 
Palaeoenvironments during a terminal Oligocene or early Miocene transgression in a fluvial system at the southwestern tip of Africa. Global and Planetary Change 150, 1-23.

582 Scott, L., Woodborne, S., 2007a. Pollen analysis and dating of Late Quaternary faecal deposits (hyraceum) in the Cederberg, Western Cape, South Africa. Review of Palaeobotany and 584 Palynology 144, 123-134.

Scott, L., Woodborne, S., 2007b. Vegetation history inferred from pollen in Late Quaternary faecal deposits (hyraceum) in the Cape winter-rain region and its bearing on past climates in South Africa. Quaternary Science Reviews 26, 941-953. Slota, P.J., Jull, A.J.T., Linick, T.W., Toolin, L.J., 1987. Preparation of small samples for ${ }^{14} \mathrm{C}$ accelerator targets by catalytic reduction of CO. Radiocarbon 29, 303-306.

Stute, M., Talma, A.S., 1998. Glacial temperatures and moisture transport regimes reconstructed from noble gas and $\delta^{18} \mathrm{O}$, Stampriet aquifer, Namibia, Isotope Techniques in the Study of Past and Current Environmental Changes in the Hydrosphere and the Atmosphere. IAEA Vienna Symposium 1997, Vienna, Austria, pp. 307-318.

Talma, A.S., Vogel, J.C., 1992. Late Quaternary paleotemperatures derived from a speleothem from Cango Caves, Cape Province, South Africa. Quaternary Research 37, 203-213.

Trabucco, A., Zomer, R.J., 2009. Global Aridity Index (Global-Aridity) and Global Potential Evapo-Transpiration (Global-PET) Geospatial Database. , in: Information, C.C.f.S. (Ed.). CGIAR-CSI GeoPortal, http://www.csi.cgiar.org.

Trauth, M.H., Foerster, V., Junginger, A., Asrat, A., Lamb, H.F., Schaebitz, F., 2018. Abrupt or gradual? Change point analysis of the late Pleistocene-Holocene climate record from Chew Bahir, southern Ethiopia. Quaternary Research, 1-10.

Tyson, P.D., 1986. Climatic Change and Variability in Southern Africa. Oxford University Press, Cape Town.

Tyson, P.D., Preston-Whyte, R.A., 2000. The Weather and Climate of Southern Africa. Oxford University Press, Cape Town.

UNEP, 1997. World atlas of desertification, 2nd ed. United Nations Environment Programme, London.

Valsecchi, V., Chase, B.M., Slingsby, J.A., Carr, A.S., Quick, L.J., Meadows, M.E., Cheddadi, R., Reimer, P.J., 2013. A high resolution 15,600-year pollen and microcharcoal record from the Cederberg Mountains, South Africa. Palaeogeography, Palaeoclimatology, Palaeoecology 387, 6-16.

van Zinderen Bakker, E.M., 1976. The evolution of late Quaternary paleoclimates of Southern Africa. Palaeoecology of Africa 9, 160-202.

Verboom, G.A., Linder, H.P., Forest, F., Hoffman, V., Bergh, N.G., Cowling, R.M., 2014. Cenozoic assembly of the greater Cape flora, in: Allsopp, N., Colville, J.F., Verboom, G.A. (Eds.), Fynbos: Ecology, Evolution and Conservation of a Megadiverse Region. Oxford University Press, Oxford, pp. 93-118.

Verboom, G.A., Nicola, G.B., Sarah, A.H., Vera, H., Matthew, N.B., 2015. Topography as a driver of diversification in the Cape Floristic Region of South Africa. The New Phytologist 207, 368-376.

Yamazaki, D., Ikeshima, D., Tawatari, R., Yamaguchi, T., O'Loughlin, F., Neal, J.C., Sampson, C.C., Kanae, S., Bates, P.D., 2017. A high-accuracy map of global terrain elevations. Geophysical Research Letters 44, 5844-5853. 


\section{Table captions}

626 Table 1: Radiocarbon ages and calibration information for the PK08, PK10-1 and PK1173 (Scott

627 and Woodborne, 2007a, b) rock hyrax middens.

\section{Figure captions}

629 Figure 1: Map of southern Africa showing seasonality of rainfall and climatic gradients dictated

630 by the zones of summer/tropical (red) and winter/temperate (blue) rainfall dominance. Major

631 atmospheric (white arrows) and oceanic (blue arrows) circulation systems are indicated.

632 Figure 2: Map of southernmost Africa showing A) showing seasonality of rainfall and climatic

633 gradients defined in terms of percentage of winter rainfall, B) the extent of the vegetation

634 types comprising the Cape Floristic Region (fynbos, renosterveld and Albany Thicket (data from

635 Mucina and Rutherford, 2006)), C) a map of mean Aridity Index values for the region (Trabucco

636 and Zomer, 2009), and D) a map of species richness using data derived from the GBIF database

637 (Chevalier, 2019; 2018; GBIF.org, 2018, b, c, d, e, f, g, h, i); number of species per quarter-

638 degree grid cell were interpolated to create the contour map. Classification of aridity values

639 follows that of the United Nations Environment Programme (1997). Sites considered in this

640 study are indicated: Pakhuis Pass (PK: this study; Scott and Woodborne, 2007a; Scott and

641 Woodborne, 2007b), De Rif (DR: Chase et al., 2015a; Chase et al., 2011; Quick et al., 2011),

642 Katbakkies Pass (KB: Chase et al., 2015b; Meadows et al., 2010), Seweweekspoort (SWP: Chase

643 et al., 2015a; Chase et al., 2013; Chase et al., 2017) and Eilandvlei (Quick et al., 2018). 
644 Figure 3: Map of the N-S axis of the Cape Fold Mountains in the southwestern Cape, including

645 the Cederberg Mountains and adjacent ranges. Topographic variability (MERIT digital elevation

646 model; Yamazaki et al., 2017) is overlain by a map of mean Aridity Index values (Trabucco and

647 Zomer, 2009) for the region, as in Figure 1. The dominant vector of temperate moisture-bearing

648 systems related to the westerly storm track is shown, as are the sites considered in this study:

649 Pakhuis Pass (this study; Scott and Woodborne, 2007a; Scott and Woodborne, 2007b), De Rif

650 (Chase et al., 2015a; Chase et al., 2011; Quick et al., 2011), Katbakkies Pass (Chase et al., 2015b;

651 Meadows et al., 2010). The relative aridity of each sites is shown on the legend. Inset indicates

652 position of the region within the southwestern Cape.

653 Figure 4: Pakhuis Pass rock hyrax middens sampled for this study: a) PK08, $7 \mathrm{~cm}$ tool atop

654 midden for scale; b) collecting a portion of the PK08 midden; c) PK10-1 midden, $16 \mathrm{~cm}$ GPS unit

655 for scale.

656 Figure 5: Age-depth models for the PK08, PK10-1 and PK1173 rock hyrax middens.

657 Figure 6: Pane (a): The $\delta^{15} \mathrm{~N}$ data from the PK08 (red), PK10-1 (blue, sample location provided 658 for lower resolution Holocene portion) and PK1173 (green) rock hyrax middens. Pane (b): The 659 same records following corrections made to establish a single composite record for the site. The 660 PK10-1 midden is associated with a more exposed foraging range and thinner soils, and a 661 0.95\% correction factor was applied based on average values from PK08 and PK1173 662 (recovered from more mesic locations) for overlapping time periods. For the $>15,500$ cal BP 663 portion of the sequence the similarly resolved, but irregularly sampled overlapping portions of 664 PK10-1 and PK1173 (dashed lines) have been combined (shown in black) using Gaussian kernel- 
665 based interpolation (Rehfeld et al., 2011). The timing of major changes as identified from the 666 composite record using change point analysis (Killick et al., 2012) are indicated by vertical 667 dashed lines.

668 Figure 7: The $\delta^{15} \mathrm{~N}$ data from the Pakhuis Pass (this paper), De Rif (Chase et al., 2011) and 669 Seweweekspoort (Chase et al., 2017) rock hyrax middens, and the sea-salt sodium flux data 670 from the EPICA Dronning Maud Land ice core from Antarctica, a proxy for sea-ice extent 671 (Fischer et al., 2007).

672 Figure 8: Holocene $\delta^{15} \mathrm{~N}$ records from the Pakhuis Pass (this paper), Katbakkies Pass (Chase et 673 al., 2015b), De Rif (Chase et al., 2015a) and Seweweekspoort (Chase et al., 2017) rock hyrax 674 middens, as well as the afrotemperate forest pollen record from Eilandvlei (Quick et al., 2018), 675 and proxies records relating to the position of the southern westerlies, including 676 reconstructions of Southern Ocean summer sea-surface temperatures and sea ice presence 677 (Nielsen et al., 2004) and the sea-salt sodium flux data from the EPICA Dronning Maud Land ice 678 core from Antarctica, a proxy for sea-ice extent (Fischer et al., 2007; Roberts et al., 2017).

679 Figure 9: Holocene western Cape Floristic Region $\delta^{15} \mathrm{~N}$ records from the Pakhuis Pass (this 680 paper), Katbakkies Pass (Chase et al., 2015b) and De Rif (Chase et al., 2015a) rock hyrax 681 middens, resampled to a common 100-year resolution (linear interpolation). Three time slices 682 have been selected across the mid-Holocene (4600, 5600 and $7000 \mathrm{cal} B P$ ), and the $\delta^{15} \mathrm{~N}$ values 683 from the sites, as proxies for water availability, have been used to interpolate the steepness of 684 hydroclimatic $\left(\delta^{15} \mathrm{~N}\right)$ gradients between the sites. White isolines are described at $0.2 \% \circ \delta^{15} \mathrm{~N}$ 685 intervals. Note, as only three sites were used in this calculation, extrapolated gradients not 
686 along the vector described by these three sites should not be considered as reliable 687 reconstructions. 